\title{
HYPERINSULINISM
}

\section{Hyperinsulinism of infancy: towards an understanding of unregulated insulin release}

\author{
Ruth M Shepherd, Karen E Cosgrove, Rachel E O'Brien, Philippa D Barnes, \\ Carina Ämmälä, Mark J Dunne on behalf of the EU funded European Network for \\ Research into Hyperinsulinism in Infancy (ENRHI)
}

\begin{abstract}
Insulin is synthesised, stored, and secreted from pancreatic $\beta$ cells. These are located within the islets of Langerhans, which are distributed throughout the pancreas. Less than $2 \%$ of the total pancreas is devoted to an endocrine function. When the mechanisms that control insulin release are compromised, potentially lethal diseases such as diabetes and neonatal hypoglycaemia are manifest. This article reviews the physiology of insulin release and illustrates how defects in these processes will result in the pathophysiology of hyperinsulinism of infancy.

(Arch Dis Child Fetal Neonatal Ed 2000;82:F87-F97)
\end{abstract}

Keywords: hypoglycaemia; ATP sensitive potassium channels; insulin secretion; nesidioblastosis; hyperinsulinism; diazoxide

Pancreatic $\beta$ cells have evolved to release insulin in response to a host of different physiological regulators: from neurotransmitters and neuropeptides, to circulating hormones, amino acids and, of course, glucose. Each of these molecules reaches the $\beta$ cell by a number of fundamentally different routes. A dense network of blood vessels keeps the islets of Langerhans informed about the nutrient and hormonal status of the blood. The islets are also richly innervated by an array of neural influences that can both inhibit and stimulate insulin release. Paracrine modulation is also important. Within the islets, somatostatin secretion from $\delta$ cells will inhibit insulin release, whereas glucagon from $\alpha$ cells will stimulate insulin secretion. Finally, $\beta$ cells are also influenced by "autoregulatory events". Insulin-for example, which has long been thought to have no effect on secretion or to have an inhibitory influence, has recently been shown to act upon $\beta$ cells through its own receptor to enhance both insulin biosynthesis and secretion. ${ }^{1-3}$ When faced with such a multitude of diverse signalling molecules, the decoding of signalling information by the cell becomes crucial. Recent progress in the area of "stimulus-response coupling" has provided new insights into the control of $\beta$ cell operation and evidence that defective processes can lead to the manifestation of disease.

In the hierarchy of insulin secretagogues, glucose is the prevailing influence. At concentrations that elicit insulin release, glucose has pronounced effects upon several aspects of $\beta$ cell function. These culminate in both "first phase" and "second phase" secretion, and the subcellular mechanisms that control these processes are in the process of being elucidated.

\section{The electric $\beta$ cell}

$\beta$ Cells are electrically active. In the presence of stimulatory concentrations of glucose (typically greater than $5.5 \mathrm{mM}$ ) they release insulin in a pulsatile manner. Oscillations in insulin secretion are dependent upon the concentration of glucose: increasing in frequency with increasing concentrations of glucose. These events are underpinned by cycles of change in the cell membrane potential, which in turn generates oscillations in the intracellular free calcium concentration. Metabolism of glucose is crucial to initiate these changes in the membrane potential. This is facilitated through the closure of potassium ion channels at the plasma membrane - the ATP sensitive $\mathrm{K}^{+}\left(\mathrm{K}_{\mathrm{ATP}}\right)$ channels. Ion channels are plasma membrane "tunnels", and under resting conditions the membrane potential in $\beta$ cells is determined by the $\mathrm{Na}^{+}-\mathrm{K}^{+}$ATPase pump and $\mathrm{K}^{+}$"leak" through open $\mathrm{K}_{\text {ATP }}$ channels. After glucose uptake and metabolism by both glucokinase (the "glucose sensor") and mitochondrial events, $\mathrm{K}_{\mathrm{ATP}}$ channels are closed as a consequence of the increased intracellular ATP/ADP ratio. $K_{\mathrm{ATP}}$ channel closure leads to a depolarisation of the cell and the opening of voltage dependent $\mathrm{Ca}^{2+}$ channels. The subsequent influx of $\mathrm{Ca}^{2+}$ down a > 10 000-fold concentration gradient, leads to a sharp rise in the cytosolic $\mathrm{Ca}^{2+}$ concentration close to the membrane, which then initiates the release of insulin by the process of exocytosis (fig 1). In this manner, $K_{\text {ATP }}$ channels control the "set point" of $\beta$ cell electrical activity, and their modulation clearly has a direct bearing on the regulated release of insulin. This has clinical implications. Thus, the selective inhibition of $\mathrm{K}_{\mathrm{ATP}}$ channels with drugs such as the antidiabetic sulphonylureas (for example, glibenclamide and tolbutamide) 
A
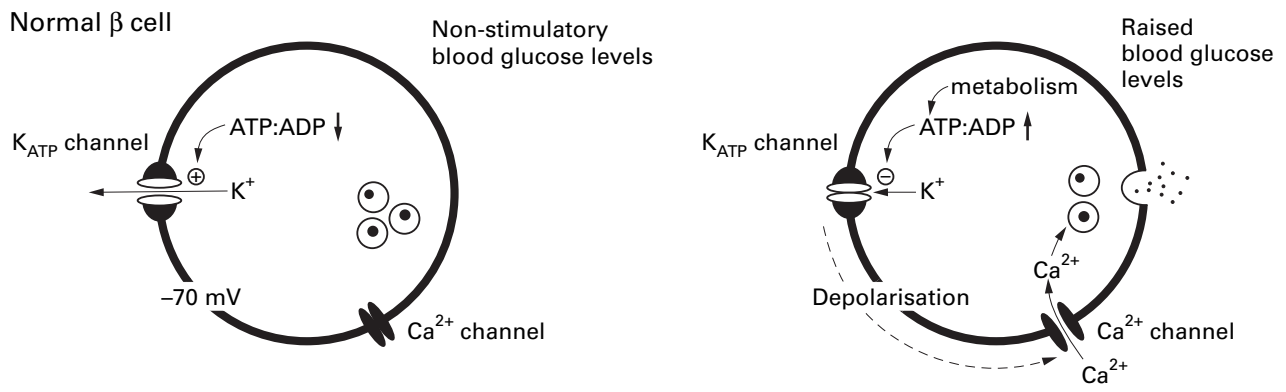

B

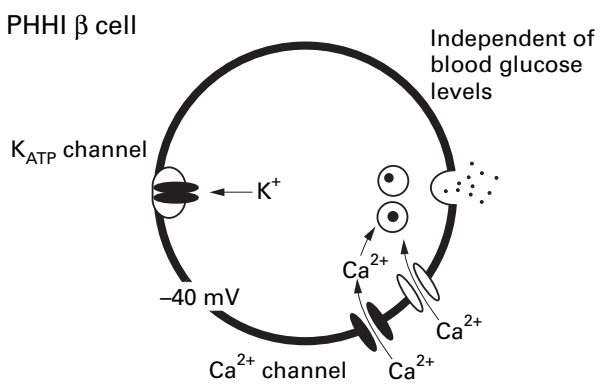

$\mathrm{C}$

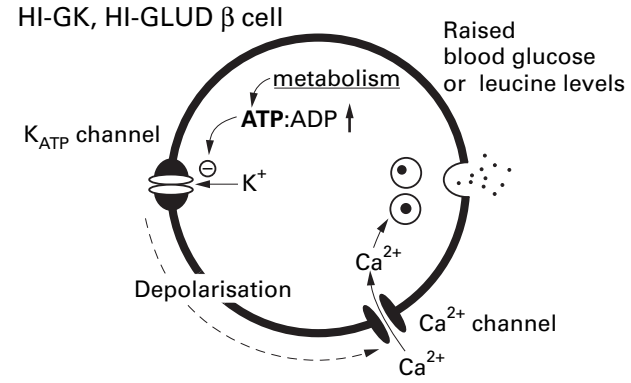

Figure 1 The ionic control of insulin release from pancreatic $\beta$ cells. (A) In normal $\beta$ cells, the resting membrane potential (approximately $-70 \mathrm{mV}$ ) is determined by open $K_{\text {ATP }}$ channels. When the extracellular glucose concentration is raised, glucose is taken up by the $\beta$ cell and glucose metabolism is initiated. The rate limiting step in this process is glucokinase and the formation of glucose-6-phosphate. Subsequent metabolic events lead to an increase in the cytosolic ATP/ADP ratio, and the closure of $K_{\text {aтp }}$ channels follows. This leads to membrane depolarisation and the opening of voltage dependent $\mathrm{Ca}^{24}$ channels. Increased $\mathrm{Ca}^{2+}$ influx then initiates the release of insulin through exocytosis of secretory granules. (B) Persistent hyperinsulinaemic hypoglycaemia of infancy (PHHI) arises from defects in either the KIR6.2 or SUR1 genes. Because these $\beta$ cells lack operational $K_{\text {ATP }}$ channels, the membrane potential is spontaneously depolarised (approximately $-40 \mathrm{mV}$ ) in the absence of glucose metabolism. This leads to the persistent activation of $\mathrm{Ca}^{2+}$ channels, causing unregulated entry of $\mathrm{Ca}^{2+}$ and persistent release of insulin as a consequence. (C) Hyperinsulinism of infancy (HI) can arise from an acquired loss of $K_{\text {ATp }}$ channel function. HI-GK and HI-GLUD are not caused by $K_{\text {aTp }}$ channel defects, but by mutations in the genes encoding either glucokinase (GK) or glutamate dehydrogenase (GLUD). These defects augment glucose and leucine metabolism in the $\beta$ cell, lead to excessive ATP production, and the enforced closure of $K_{\text {ATP }}$ channels. This is thought to cause inappropriate membrane depolarisation and unregulated $\mathrm{Ca}^{2+}$ entry.

will mimic the actions of glucose and promote insulin release. Conversely, $\mathrm{K}_{\text {ATP }}$ channel "openers", such as the hyperglycaemia inducing compound diazoxide, will exert the opposite effect and inhibit secretion by preventing voltage dependent $\mathrm{Ca}^{2+}$ entry. ${ }^{4}$ Direct inhibition of voltage gated $\mathrm{Ca}^{2+}$ channels with antagonists, such as verapamil and nifedipine, will similarly inhibit secretion from $\beta$ cells. ${ }^{5}$

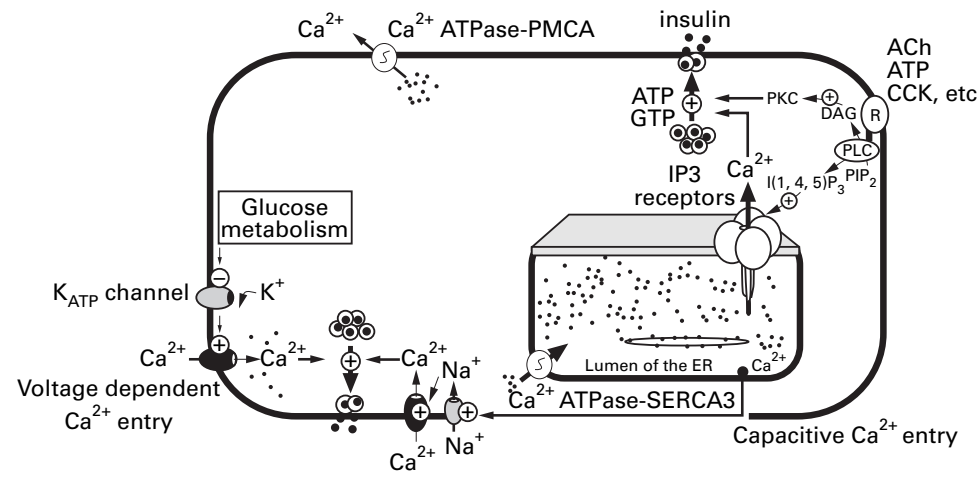

Figure 2 Intracellular $\mathrm{Ca}^{2+}$ homeostasis in pancreatic $\beta$ cells. The regulation of $\mathrm{Ca}^{2+}$ mediated insulin release is governed by: (1) $\mathrm{Ca}^{2+}$ efflux controlled by plasma membrane $C a^{2+}$-ATPases (PMCA); (2) $\mathrm{Ca}^{2+}$ sequestration by sarcoendoplasmic reticulum $C \mathrm{a}^{2+}$-ATPases (SERCA); (3) mobilisation from internal stores; and (4) $\mathrm{Ca}^{2+}$ entry through voltage gated $\mathrm{Ca}^{2+}$ channels and capacitive $\mathrm{Ca}^{2+}$ entry. Capacitive $\mathrm{Ca}^{2+}$ entry is linked to internal store content by the activity of non-selective cation channels $\left(I_{C R A N}\right)$. Once open, $\mathrm{Na}^{+}$influx causes a depolarisation of the cell and the activation of voltage gated $\mathrm{Ca}^{2+}$ channels. ACh, acetylcholine; CCK, cholecystokinin; DAG, diacylglycerol; ER, endoplasmic reticulum; $I(1,4,5) P_{3}$, inositol $(1,4,5)$ trisphosphate; $P I P_{2}$, phosphatidylinositol $(3,4,5)$ bisphosphate; PLC, phospholipase $C$.

\section{Controlling the $\mathrm{Ca}^{2+}$ signal}

In $\beta$ cells (as in all cell systems) entry of $\mathrm{Ca}^{2+}$ across the plasma membrane $\left(\mathrm{Ca}^{2+}\right.$ influx) is only one of the processes that govern intracellular $\mathrm{Ca}^{2+}$ homeostasis (fig 2). Such is the dominance of $\mathrm{Ca}^{2+}$ as an obligatory signalling molecule, that inside $\beta$ cells the concentration of $\mathrm{Ca}^{2+}$ is buffered to diminishingly small values. This is maintained by "extrusion" of $\mathrm{Ca}^{2+}$ across the plasma membrane and "sequestration" of $\mathrm{Ca}^{2+}$ into internal $\mathrm{Ca}^{2+}$ storage organelles by the energy requiring $\mathrm{Ca}^{2+}$ ATPases-plasma membrane $\mathrm{Ca}^{2+}$ ATPases (PMCA) and sarcoendoplasmic reticulum $\mathrm{Ca}^{2+}$ ATPases (SERCA), respectively. The activity of these pumps is exquisitely coordinated with mechanisms responsible for $\mathrm{Ca}^{2+}$ influx (ion channels) and $\mathrm{Ca}^{2+}$ release (mobilisation) from intracellular stores. This mainly occurs through inositol $(1,4,5)$ trisphosphate receptor gated $\mathrm{Ca}^{2+}$ channels, but there is also evidence that ryanodine receptor mediated events might be involved. In addition, $\beta$ cells have developed a direct mechanism to aid in the refilling of internal stores in the presence of maintained stimulation. The concentrations of $\mathrm{Ca}^{2+}$ contained within sarcoendoplasmic reticulum structures mainly govern "capacitive $\mathrm{Ca}^{2+}$ entry". As yet, we have an incomplete understanding of how the communication is established and how it is regulated in $\beta$ cells. Candidate genes such as 


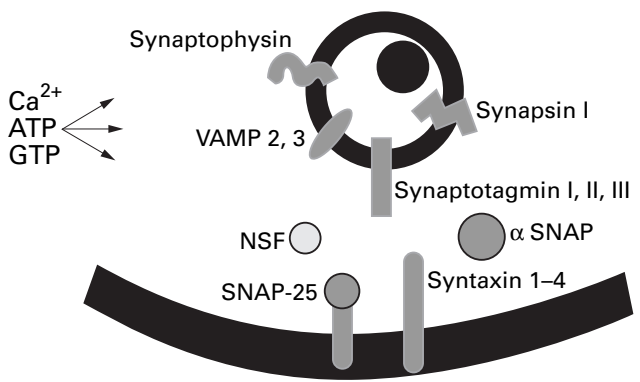

Figure 3 The components of regulated exocytosis in pancreatic $\beta$ cells. Multiple components control the late stages of stimulus-secretion coupling and exocytosis. These include the granule associated proteins synapsin 1, synaptophysin, VAMP (vesicle associated membrane protein)/synaptobrevin and synaptotagmin. NSF (N-ethylmaleimide sensitive factor) and SNAPs (soluble NSF attachment proteins) are located in the cytosol, whereas syntaxin and $S N A P-25$ are found on the plasma membrane. For docking of the secretory granule to occur, the VAMP/synaptobrevin ( $v-S N A R E$ ) in the granule membrane binds to syntaxin and SNAP-25 (these two make up "t-SNARE") in the plasma membrane. Subsequently, NSF and SNAPs complete the formation of the fusion complex that leads finally to exocytosis.

TRP and TRPL, and " $\mathrm{Ca}^{2+}$ release activated non-selective ion channels ( $\left.\mathrm{I}_{\mathrm{CRAN}}\right)$ )" appear to be involved. It is thought that after depletion of $\mathrm{Ca}^{2+}$ from internal stores, $\mathrm{Na}^{+}$entry through these channels leads to a depolarisation of the cell membrane potential and the activation of voltage gated $\mathrm{Ca}^{2+}$ channels. ${ }^{6}$ What is not clear is how the internal $\mathrm{Ca}^{2+}$ stores are able to signal to the cell membrane, nor how this is regulated.

\section{Regulating insulin release}

Glucose metabolism coupled to $\mathrm{K}_{\text {АтP }}$ channel activity governs first phase insulin release: the secretion-by exocytosis - of preprepared insulin containing granules. If we use the information established in yeast and neuronal systems for ongoing studies in the $\beta$ cell, it is possible to predict the distal steps associated with the regulated release of insulin. Upon $\beta$ cell activation, the granules have to be translocated to the plasma membrane. Even though some granules might be present at the membrane and available for exocytosis before cell activation, sustained secretion requires that translocation occurs as a regulated process. After this, the granules must dock; they are then primed for the final event, which is fusion of the granule membrane with the plasma membrane, followed by exocytosis. Subsequently, endocytosis must succeed exocytosis

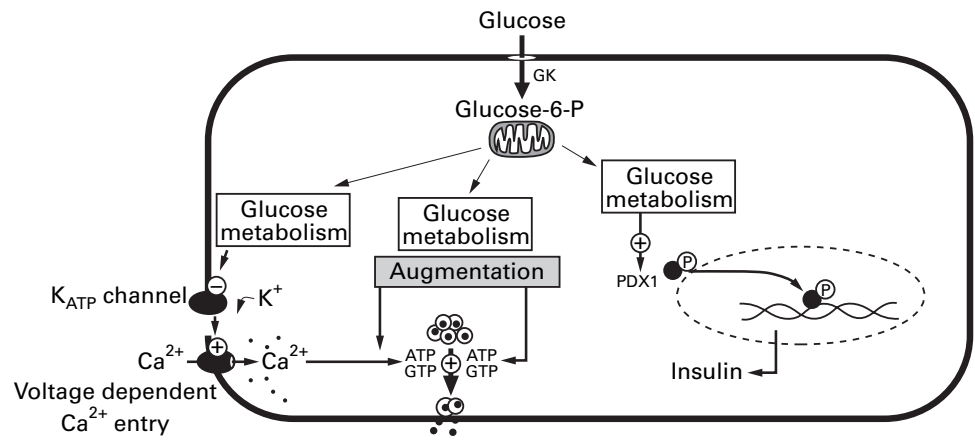

Figure 4 The control of insulin release from pancreatic $\beta$ cells. Glucose metabolism is responsible for: (1) $K_{A T P}$ channel dependent $\mathrm{Ca}^{2+}$ influx leading to insulin release; (2) $K_{A T P}$ channel independent pathways of glucose augmentation; and (3) insulin biosynthesis. to complete the cycle and allow the cell to continue to secrete insulin for lengthy periods. Without doubt, this simple classification of the late stages of stimulus-secretion coupling understates the complexity of the overall mechanism. The sequence of reactions leading to insulin release will involve many interacting moieties and different isoforms in keeping with the "SNARE (SNAP receptor) hypothesis". Figure 3 illustrates a minimal description of the components of this process in $\beta$ cells (recently reviewed by Lang $^{8}$ ).

A second important mechanism in the control of glucose dependent insulin secretion has been documented as the " $K_{\text {ATP }}$ channel independent pathway" of glucose action. ${ }^{9}$ This pathway leads to "augmented" insulin release in the presence of raised cytosolic $\mathrm{Ca}^{2+}$ concentrations (raised by the $\mathrm{K}_{\mathrm{ATP}}$ channel dependent pathway of glucose signalling) (fig 4). Experimentally, the pathway can be demonstrated by causing $\mathrm{Ca}^{2+}$ entry under conditions that prevent $\mathrm{K}_{\mathrm{ATP}}$ channel operation-for example, with diazoxide (which pharmacologically activates the $\mathrm{K}_{\text {ATP }}$ channels) or sulphonylureas (which inhibit $\mathrm{K}_{\mathrm{ATP}}$ channels). ${ }^{9-14}$ With the $\mathrm{K}_{\mathrm{ATP}}$ channels clamped, glucose induces a concentration dependent augmentation of insulin secretion, which is responsible for second phase insulin release. The mechanisms that govern this effect are largely unresolved. However, it is recognised that glucose metabolism is fundamentally required, and that the site of action is distal to the rise in intracellular $\mathrm{Ca}^{2+}$. As an additional level of complexity, $K_{\text {ATP }}$ channel independent actions of glucose to augment insulin release have also been shown to occur independently of raised cytosolic $\mathrm{Ca}^{2+} \cdot{ }^{15}$ This glucose augmentation pathway involves the simultaneous activation of protein kinases $A$ and C (as would occur during exposure to hormones, neuropeptides, and neurotransmitters) and is dependent upon ATP and GTP availability to fuel the process of exocytosis.

\section{Replenishing the reserves of insulin}

Concomitant with the control of second phase insulin secretion, glucose also stimulates the production of new insulin molecules by the translation of preformed mRNA encoding insulin (within minutes), and over longer periods of time (hours) by increased transcription of the insulin gene. One key element in linking cytosolic events to nuclear signalling is the homeodomain transcription factor PDX $1 .^{16}$ Glucose metabolism causes phosphorylation of PDX1 and translocation of the transcription factor to the nucleus. In addition to insulin, PDX1 also binds to the promoter regions of a number of other genes preferentially expressed in the $\beta$ cell, including those encoding glucose transporter GLUT-2, glucokinase, and islet amyloid polypeptide. Because PDX1 is also an important factor determining lineage in $\beta$ cell development ${ }^{17}$ it is not surprising that defects in the PDX1 gene cause maturity onset diabetes in the young type 4 and pancreatic agenesis. The role of PDX1, or indeed other similar molecules, in hyperinsulinism of infancy $(\mathrm{HI})$ has not been critically examined. 
However, it is interesting to note that impaired PDX1 activity is a phenotypic feature of the persistent hyperinsulinaemic hypoglycaemia of infancy (PHHI) derived human $\beta$ cell line, NES2Y (see below). ${ }^{18}$ Whether this is a primary defect, or a consequence of the loss of $\mathrm{K}_{\mathrm{ATP}}$ channels in the $\beta$ cell has yet to be determined.

Controlling the coordinated release of insulin from $\beta$ cells in response to physiological agents is clearly a highly integrated but ordered process. Recent advances in the field of $\beta$ cell physiology have provided new insights into these processes. Equally important have been advances in the area of the pathogenesis of insulin release. One of the most compelling examples of the integration of physiology with pathophysiology has been the revelation that $\mathrm{HI}$ caused by PHHI is a $\mathrm{K}_{\mathrm{ATP}}$ channelopathy.

\section{$K_{\text {ATP }}$ channel structure and regulation}

$\beta$ Cells express a $K_{\mathrm{ATP}}$ channel complex formed by subunits belonging to at least two distinct families of proteins (recently reviewed ${ }^{19}{ }^{20}$ ) (fig $5)$. The $\mathrm{K}^{+}$selective pore is formed by the Kir6.2 subunit, a member of the inward rectifier $\mathrm{K}^{+}$channel family. Kir6. 2 comprises 390 amino acids, and has a predicted membrane topology, with two $\alpha$-helical transmembrane domains linked by a highly conserved sequence of amino acids. Because this linking region shares sequence homology with the $\mathrm{P}$ or $\mathrm{H} 5$ region of voltage gated $\mathrm{K}^{+}$channels, it is thought to be important for the control of $\mathrm{K}^{+}$selectivity through the pore (fig 5). The other subunit, a larger protein, is a receptor with high affinity for sulphonylureas, designated SUR1. ${ }^{21}$ Two closely related genes encode two sulphonylurea receptors, SUR1 and SUR2. ${ }^{22}$ Three splice variants of the SUR2 gene have been described and designated, SUR2A, SUR2B, and SUR2C. ${ }^{19}$ Human SUR1 is 1581 amino acids in length and like the cystic fibrosis transmembrane conductance regulator and the multidrug resistance protein it is a member of the superfamily of ATP binding cassette proteins. SUR1 has 17 predicted transmembrane domains (TMDs) ${ }^{23}$ organised into three regions (TMD0, TMDI, and TMDII), and two intracellularly disposed nucleotide binding domains
(NBDs) (fig 5). Neither the native Kir6.2 subunit nor the SUR1 subunit will form operational $\mathrm{K}^{+}$channels independently. However, when coexpressed, $\mathrm{K}^{+}$channel currents are generated that closely resemble those of the native $\beta$ cell $\mathrm{K}_{\mathrm{ATP}}$ channel complex. ${ }^{2425} \mathrm{~K}_{\mathrm{ATP}}$ channels in other tissues are heteromultimeric complexes of different Kir6.x and SUR proteins-for example, cardiac muscle: Kir6.2 + SUR2A; smooth muscle: Kir6.2 + SUR2B; and the smooth muscle nucleotide activated channel: Kir6.1 + SUR2B. ${ }^{19}$

\section{SUR1, Kir6.2, and regulation of $K_{\mathrm{ATP}}$ channels}

The topological organisation of the $\mathrm{K}_{\mathrm{ATP}}$ channel is thought to be that of an obligatory octameric complex, formed by four Kir6.2 subunits lining the pore, coupled to four SUR1 subunits-(SUR1 + Kir6.2) ${ }_{4}$ (fig 5B)..$^{27}$ Through molecular biology techniques, recent advances have been made in determining what contribution each of the subunits makes to the properties of the channel complex. Kir6.2 determines the biophysical properties, such as the correct ion selectivity, rectification and "gating" properties of the complex. ${ }^{19} 20$ The sensitivity of $K_{\text {ATP }}$ channels to physiological regulators, such as the adenine (ATP, ADP) and guanosine (GTP, GDP) nucleotides, is a complex process involving both subunits. Kir6.2 is thought to be the major site for ATP binding and ATP induced channel closure, whereas ADP (and GDP) interacts with one of the nucleotide binding domains of SUR 1.192028 In this manner, both subunits are important for ATP/ADP mediated $K_{\text {ATP }}$ channel activity, with the actions of ADP on SUR1 antagonising the effects of ATP at Kir6.2. SUR1 influences the trafficking and distribution of Kir6.2, but both subunits contribute to the ordered assembly and location of the complex at the plasma membrane. ${ }^{29}{ }^{30}$ The protein kinase $\mathrm{A}$ induced phosphorylation of $\mathrm{K}_{\mathrm{ATP}}$ channels, as would occur during stimulation of the $\beta$ cell with receptor mediated events such as glucagon-like protein, gastric inhibitory peptide, and pituitary adenylate cyclase activating peptide (GLP-1, GIP, and PACAP), also involves both SUR1 and Kir6.2. ${ }^{31}$

A

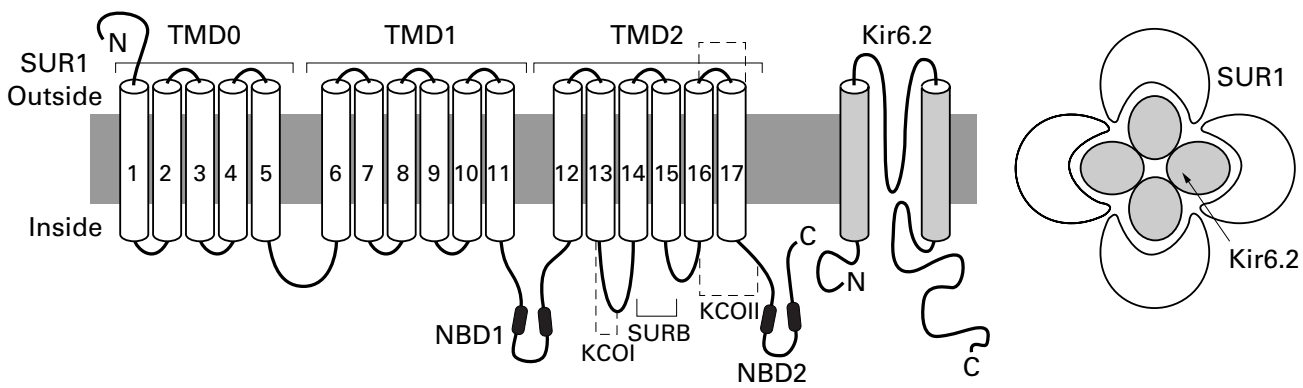

Figure 5 Components of $K_{\text {ATP }}$ channels in pancreatic $\beta$ cells. (A) The predicted topology of the $K^{+}$channel subunit, SUR1, an ATP binding cassette protein. Note the characteristically high number of transmembrane spanning domains 1-17 and the two intracellularly disposed nucleotide binding domains (NBDs). Also shown are the predicted sites for potassium channel opener binding (KCOI, KCOII) and sulphonylurea binding (SURB). Note that these are located towards the $C$-terminal region of the molecule. Kir6.2 has two transmembrane domains and an inner loop that controls $K^{+}$ influx. (B) The heteromultimeric $K_{\text {ATp }}$ channel complex is an obligatory octameric structure composed of (Kir6.2/SUR1) ${ }_{4}$. Kir6. 2 is located toward the centre of the complex. 
Pharmacological regulation of $\mathrm{K}_{\mathrm{ATP}}$ channels is also governed by interactions with each of the subunits, but interestingly different classes of agents appear to regulate differentially either SUR1 or Kir6.2. Antidiabetic sulphonylureas have a low affinity binding site on Kir6.2, but bind with high affinity to SUR1. ${ }^{32}$ The sulphonylurea receptor binding site (SURB) is currently thought to lie between the transmembrane sequences 14-16 (residues 1035-1277) ${ }^{32}$ in the TMDII part of the molecule (fig 5B), and occupancy of just one of the four SURBs in each complex is enough to induce channel closure. ${ }^{34}$ The identification of SURB at this particular site has implications for the selective regulation of $\mathrm{K}_{\text {ATP }}$ channels across tissues. For example, tolbutamide has no effect on cardiac channels, and although glibenclamide will block both $\beta$ cell and cardiac $\mathrm{K}_{\mathrm{ATP}}$ channels, its effects are readily reversible in cardiac tissue, but not in insulin secreting cells. ${ }^{35}$ Such differences arise from the fact that even though SUR2A, the SUR component of the cardiac $\mathrm{K}_{\text {ATP }}$ channel, is approximately $70 \%$ homologous to SUR1, ${ }^{36}$ the molecules are predominantly different towards the C-terminal region; that is, the part of SUR containing the SURB. In contrast to the effects of sulphonylureas on $\mathrm{K}_{\mathrm{ATP}}$ channels, insulinotropic agents such as the imidazoline phentolamine close $\mathrm{K}_{\mathrm{ATP}}$ channels by a direct interaction with Kir6.2 rather than SUR1. ${ }^{37}$

SURs are also important in determining the pharmacological regulation of $\mathrm{K}_{\mathrm{ATP}}$ channels by "potassium channel openers" such as diazoxide, which is used in the treatment of HI, and levcromakalim, pinacidil, and nicorandil. Most potassium channel openers will activate vascular and cardiac $\mathrm{K}_{\mathrm{ATP}}$ channels $^{38}$; however, only diazoxide $^{4}$ and diazoxide derivatives ${ }^{39}$ are effective against the $\beta$ cell $\mathrm{K}_{\mathrm{ATP}}$ channels. ${ }^{40}$ As with the effects of sulphonylureas on SURs, the explanation for this appears to be the location of the potassium channel opener binding site. Using a series of chimaeric SUR protein derivatives of SUR1 and SUR2, Uhde and colleagues $^{33}$ have shown that two sequences of SUR1 are crucial for determining potassium channel opener binding and $\mathrm{K}_{\mathrm{ATP}}$ channel activation. These are located within the final series of TMDs at amino acids 1059-1087 (potassium channel opener I) and 1218-1320 (potassium channel opener II), which correspond to part of the linking sequence between TMDs 13-14 and TMD sequence 16-17 (fig $5 \mathrm{~A})$. These regions flank the putative SURB site, and are thought to form a binding pocket for diazoxide on the $\beta$ cell $\mathrm{K}_{\text {ATP }}$ channel. ${ }^{33}$ Although the stoichiometry for diazoxide has yet to be determined, based upon studies of the effects of potassium channel openers on SUR $2,{ }^{33}$ it seems likely that four molecules of the drug are required to initiate opening of the channels. No mutations in these sequences of amino acids have yet been reported in patients with PHHI (table 1), but clearly defects in this part of SUR1 could result in insensitivity to diazoxide in vivo.

\section{Gene defects and HI}

The gene encoding SUR1 comprises 39 exon boundaries and is clustered with the KIR6.2 gene- - a single open reading frame lying immediately 3 ' of the SUR1 gene and separated by only 4.5 kilobase pairs. ${ }^{52}$ Their location in the human genome on the short arm of chromosome 11 corresponds to a genetic locus linked to familial forms of a potentially lethal childhood disorder associated with persistent hypoglycaemia as a result of HI (B Glaser et al, 1999, unpublished). ${ }^{53}$ The evidence is now convincing that gene defects within SUR1 or KIR6.2 can be correlated with the functional loss of $\mathrm{K}_{\mathrm{ATP}}$ channels in $\beta$ cells. However, this does not cause insulin hypersecretion per se; rather, loss of these channels leads to a dysregulation of $\mathrm{Ca}^{2+}$ homeostasis in $\beta$ cells and unregulated insulin release is a consequence.

\section{$\mathrm{K}_{\mathrm{ATP}}$ channels and $\mathrm{HI}$}

Hypoglycaemia is a relatively common childhood metabolic abnormality and when persistent or recurrent is most frequently a consequence of hyperinsulinism: neonatal hyperinsulinism (OMIM:256450). Until recently, the pathophysiology of this group of conditions was not understood, although a defect in $\beta$ cell function was first suggested in 1981, when it was shown that glucose failed to promote a concentration dependent release of insulin in tissue isolated from a child with hyperinsulinaemia induced hypoglycaemia. ${ }^{54}$

\section{PHHI}

PHHI is a severe form of $\mathrm{HI}$, and a condition that is usually unresponsive to medical treatment and associated with profound hypoglycaemia in the early neonatal period. Sporadic cases are thought to be rare in the general population (approximately one in 45000 ), but the disease has an incidence in communities with high rates of consanguinity approaching that of cystic fibrosis in white European populations-approximately one in 2500 live births. ${ }^{53}$ Severe forms usually present within the first few hours or days of birth, as the result of extreme and sustained low blood glucose concentrations caused by unregulated secretion of insulin. Failure to recognise and promptly treat hypoglycaemia carries a substantial risk of severe brain damage and mental retardation because of a lack of fuels to sustain normal brain metabolism (for review see Glaser and colleagues ${ }^{53}$ ). Medical treatment for the disorder involves an increased carbohydrate intake to meet the raised requirement, and usually one or more drugs that inhibit insulin secretion. These agents include diazoxide, which was first introduced to treat hyperinsulinism in the 1960 s, and somatostatin, both of which will activate $K_{A T P}$ channels in normal $\beta$ cells and inhibit insulin release. ${ }^{4}$ This occurs as a result of increased $\mathrm{K}^{+}$channel opening causing a hyperpolarisation of the membrane and closure of voltage dependent $\mathrm{Ca}^{2+}$ channels. Unfortunately, however, the responsiveness of children with PHHI to these agents is highly variable, and patients who do not show an adequate and immediate response 
require surgery to remove their pancreasusually a $95 \%$ pancreatectomy - to prevent recurrent hypoglycaemia. The variability in sensitivity to medical treatment is largely unexplained, but defects in the ionic control of insulin release prevail in PHHI $\beta$ cells, and these can largely account for the findings. ${ }^{5-57}$ Pancreatectomy usually induces a clinical remission of symptoms, but this procedure will invariably predispose the patient with PHHI to pancreatic insufficiency and the development of diabetes mellitus in later life.

\section{The correlation of $K_{\mathrm{ATP}}$ channel defects} with PHHI

The genetic basis of PHHI has not been determined conclusively. ${ }^{53}$ In those cases where mutations have been linked to the disease, ${ }^{58}$ defects in the SUR1 and KIR6.2 genes are mainly, but not exclusively, inherited in an autosomally recessive manner (table 1 ). ${ }^{41}$ Gene defects in SUR1 can also be inherited differently. In these cases, the patient inherits a single paternal recessive SUR1 gene mutation, and a part of the pancreas is reduced to hemizygosity because of the loss of maternal

Table 1 Mutations found in patients with persistent hyperinsulinaemic hypoglycaemia of infancy (PHHI) within the SUR1 and KIR6.2 genes

\begin{tabular}{|c|c|c|c|c|c|}
\hline $\begin{array}{l}\text { Mutation } \\
\text { designation }\end{array}$ & $\begin{array}{l}\text { Exon or } \\
\text { intron }\end{array}$ & $\begin{array}{l}\text { Codon predicted } \\
\text { change }\end{array}$ & Domain & $\begin{array}{l}\text { Restriction } \\
\text { site change }\end{array}$ & Refs \\
\hline \multicolumn{6}{|l|}{ SUR1 } \\
\hline \multirow[t]{2}{*}{ c. $221 \mathrm{G}>\mathrm{A}$} & Exon 2 & $\mathrm{R} 74 \mathrm{Q}$ & $\mathrm{Tm}$ & PstI & 41 \\
\hline & Exon 3 & A116P & $\mathrm{Tm}$ & Bbv1 & 28 \\
\hline \multirow[t]{2}{*}{ c. $375 C>G$} & Exon 3 & H125Q & - & Ddel & 41 \\
\hline & Exon 4 & V187D & $\mathrm{Tm}$ & & 42 \\
\hline \multirow[t]{5}{*}{ c. $563 \mathrm{~A}>\mathrm{G}$} & Exon 4 & N188S & $\mathrm{Tm}$ & TspRI & 41 \\
\hline & Exon 5 & 679 ins $18 \mathrm{nt}$ & & & 28 \\
\hline & Exon 5 & 731 del a & & & 28 \\
\hline & Exon 5 & L226 ins 5 aa & & & 28 \\
\hline & Exon 5 & $\mathrm{R} 248 \mathrm{X}$ & & & 28 \\
\hline c.949delC & Exon 6 & $317 \mathrm{fs} /$ ter & $\mathrm{Tm}$ & Bsp1286I & 41 \\
\hline \multirow[t]{2}{*}{ c. $1216 \mathrm{~A}>\mathrm{G}$} & Exon 8 & $\mathrm{~N} 406 \mathrm{D}$ & - & $\mathrm{XcmI}$ & 41 \\
\hline & Exon 8 & $\mathrm{C} 418 \mathrm{R}$ & & BglII & 28 \\
\hline \multirow[t]{2}{*}{1260 ins 31 bases } & Exon 8 & Insertion of $31 \mathrm{bp}$ & & & 28 \\
\hline & Exon 10 & L508P & & MspA1, MspBII & 28 \\
\hline c. $1630+1 G>T$ & Intron 10 & Aberrant splicing & - & BsrI & 41 \\
\hline c. $1671-20 A>G$ & Intron 11 & Aberrant splicing & - & SpeI & 43 \\
\hline \multirow{3}{*}{ c. $1773 \mathrm{C}>\mathrm{G}$} & Exon 12 & F591L & $\mathrm{Tm}$ & BsoFI & 41 \\
\hline & Exon 13 & R620C & & XhoII & 28 \\
\hline & Exon 13 & H627X & & & 28 \\
\hline c. $1885 \mathrm{del} \mathrm{C}$ & Exon 13 & & & & 28 \\
\hline c.1893delT & Exon 13 & $631 \mathrm{fs} /$ ter & - & BstNI & 41 \\
\hline c. $2117-1 \mathrm{G}>\mathrm{A}$ & Intron 15 & Aberrant splicing & NBD-1 & PstI & 41 \\
\hline c. $2147 \mathrm{G}>\mathrm{T}$ & Exon 16 & G716V & NBD-1 & BbvI & 43 \\
\hline \multirow[t]{3}{*}{ c. $2291-1 \mathrm{G}>\mathrm{A}$} & Intron 18 & Aberrant splicing & NBD-1 & BstNI & 43 \\
\hline & Exon 21 & R836X & NBD-1 & Bsr1 & 44 \\
\hline & Exon 21 & R842G & NBD-1 & & Glaser et al, 1999 \\
\hline \multirow[t]{2}{*}{ c. $2860 \mathrm{C}>\mathrm{T}$} & Exon 24 & Q954X & - & BstNI & 41 \\
\hline & Exon 24 & S957F & & & 28 \\
\hline c. $3416 \mathrm{C}>\mathrm{T}$ & Exon 28 & $\mathrm{~T} 1139 \mathrm{M}$ & - & NiaIII & 41 \\
\hline c. $3651-1 \mathrm{G}>\mathrm{T}$ & Intron 29 & & & & 28 \\
\hline c. $3644 \mathrm{G}>\mathrm{A}$ & Exon 29 & R1215Q & - & Stul & 41 \\
\hline c. $3992-9 \mathrm{G}>\mathrm{A}$ & Intron 32 & Aberrant splicing & NciI & & 43,45 \\
\hline \multirow{3}{*}{ c. $3992-3 C>G$} & Intron 32 & Aberrant splicing & AvaI & & 41 \\
\hline & Exon 33 & $\mathrm{~K} 1337 \mathrm{~N}$ & & & Glaser et al, 1999 \\
\hline & Exon 33 & W1338X & Bstx1 & & 29 \\
\hline \multirow[t]{2}{*}{ c. $4058 \mathrm{G}>\mathrm{C}$} & Exon 33 & $\mathrm{R} 1352 \mathrm{P}$ & hHal & & 46 \\
\hline & Exon 33 & V1360M & BsrFI & & 28 \\
\hline c. del4138 CGAC & & & NBD-2 & & 47 \\
\hline c. 4144 (complex) & & & NBD-2 & & 28 \\
\hline c. $4135 \mathrm{G}>\mathrm{C}$ & Exon 34 & G1379R & NBD-2 & EagI & 41 \\
\hline \multirow[t]{2}{*}{ c. $4144 \mathrm{G}>\mathrm{A}$} & Exon 34 & G1382S & NBD-2 & $\mathrm{Bg} 1 \mathrm{I}$ & 41 \\
\hline & Exon 34 & $\mathrm{~S} 1387 \mathrm{~F}$ & NBD-2 & Mnl1 & 28 \\
\hline c. 4162 delTTC & Exon 34 & F1388del & NBD-2 & BseRI & 45 \\
\hline \multirow[t]{2}{*}{ c. $4181 \mathrm{G}>\mathrm{A}$} & Exon 34 & $\mathrm{R} 1394 \mathrm{H}$ & NBD-2 & BflM1 & 41 \\
\hline & Exon 35 & R1419C & NBD-2 & Hhal & 28 \\
\hline c. $4261 \mathrm{C}>\mathrm{T}$ & Exon 35 & $\mathrm{R} 1421 \mathrm{C}$ & NBD-2 & NiaIII & 28,46 \\
\hline \multirow[t]{2}{*}{ c. $4310 \mathrm{G}>\mathrm{A}$} & Exon 35 & $\begin{array}{l}\mathrm{R} 1437 \mathrm{Q}(23) \mathrm{X} \text {, aberrant } \\
\text { splicing }\end{array}$ & NBD-2 & MspI & $28,43,48,49$ \\
\hline & Exon 36 & $\mathrm{~A} 1457 \mathrm{~T}$ & NBD-2 & & 42 \\
\hline \multirow[t]{3}{*}{ ND } & Exon 37 & G1479R & NBD-2 & AciI & 28,50 \\
\hline & Exon 37 & $4415-13 \mathrm{G}>\mathrm{A}$ & & Ncil & 28 \\
\hline & Exon 37 & A1493T & & & Glaser et al, 1999 \\
\hline c. $4480 \mathrm{C}>\mathrm{T}$ & Exon 37 & R1494W & NBD-2 & Smal & 28,46 \\
\hline & Exon 37 & R1494Q & NBD-2 & & Glaser et al, 1999 \\
\hline c. 4525 ins 4 bases & Exon 37 & $\begin{array}{l}\text { Insertion of AlaSer after } \\
\text { codon } 1508\end{array}$ & NBD-2 & PvuII & 41 \\
\hline & Exon 37 & F1506K & NBD-2 & & 51 \\
\hline & Exon 38 & E1507K & NBD-2 & Mnl1 & 28 \\
\hline & Exon 39 & $\mathrm{~L} 1544 \mathrm{P}$ & & & 28 \\
\hline KIR6.2 & & & & & \\
\hline c. $649 \mathrm{~T}>\mathrm{C}$ & Exon 1 & L147P & & PvuI, Ava1 & 50 \\
\hline & Exon 1 & W $91 \mathrm{R}$ & & AciI & 29 \\
\hline c. $39 \mathrm{C}>\mathrm{A}$ & Exon 1 & $\mathrm{~T} 12 \mathrm{X}$ & & BsaAI & 50 \\
\hline
\end{tabular}

Tm, putative transmembrane domain (according to Swiss-Prot Q09428); NBD, nucleotide binding domain; ND, no data available; M2 region, one of two potential transmembrane spanning domains; nt nucleotide; bp base pairs. 
imprinted genes. ${ }^{4659}$ Loss of heterozygosity in the affected $\beta$ cells results in insulin hypersecretion, but because of the loss of other maternally expressed imprinted genes (such as the tumour supressor genes $\mathrm{H} 19$ and $\mathrm{p} 57^{\mathrm{KIP} 2}$ ), the pancreata of patients with this condition also have a morphologically distinctive appearance, with focal regions of $\beta$ cell hyperproliferation. This has given rise to the term "focal PHHI" as distinct from "diffuse PHHI", which is not associated with the loss of imprinted genes. ${ }^{47}$

For a number of SUR1 and KIR6.2 mutations that have been described it has now been shown that these gene defects can produce a variety of abnormalities in recombinant $\mathrm{K}_{\text {АTP }}$ channel function, including trafficking defects, assembly defects, and regulatory problems. $^{58}$ However, very few studies have been undertaken in $\beta$ cells isolated from patients with the disease. There are perhaps two reasons. First, it is technically difficult to isolate $\beta$ cells from human tissue. Second, the amounts of tissue available for experimental studies after processing of the pancreas are extremely small. We have now undertaken studies on 49 patients with PHHI, and this work has been used to provide a crucial link between documenting gene variations in SUR1 and KIR6.2 and the clinical manifestation of hyperinsulinaemia induced hypoglycaemia.

Patch clamp studies (fig 6) require very limited amounts of primary tissue, and at the same time provide precise details about the molecular mechanisms of cellular control. Thus, using insulin secreting cells isolated after pancreatectomy, these experiments have shown that $\mathrm{K}_{\mathrm{ATP}}$ channels are defective in PHHI $\beta$ cells. 42485560 The integration of PHHI $\beta$ cell physiology with patient genotyping for KIR6.2 and SUR1 related defects is clearly an important consideration in these studies. In some studies, we have documented the complete absence of any operational $\mathrm{K}_{\mathrm{ATP}}$ channels (R1437Q(23)X), ${ }^{48}$ whereas in another tissue, $\mathrm{K}_{\mathrm{ATP}}$ channels were recorded, but they were devoid of regulation (exon 4, V187D mutation). ${ }^{42}$ It has not been possible to identify SUR1/KIR6.2 defects in all the patients studied, but the prevailing observations are that the loss of a crucial number of functional channels prevents the PHHI $\beta$ cells from regulating the cell membrane potential.

In isolated PHHI $\beta$ cells it has been found that the resting cell membrane potential is

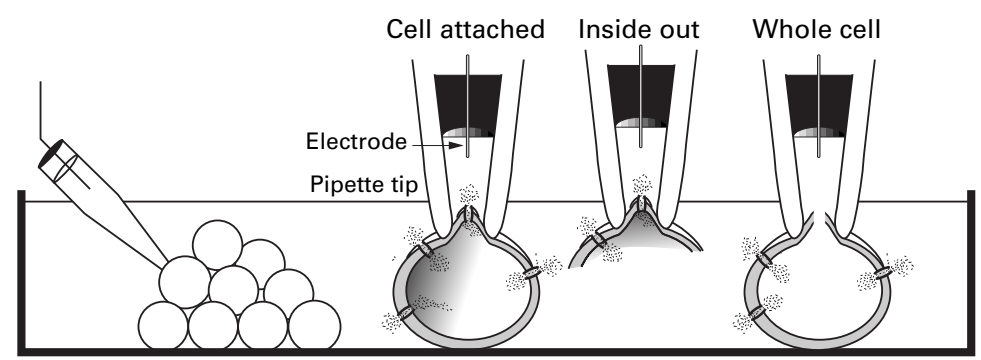

Figure 6 Patch clamp studies of ion channels in $\beta$ cells. Patch clamp recordings are generated by "sealing" a glass micropipette (tip diameter $\sim 1 \mu \mathrm{m}$ ) against the outer membrane of a cell. Three of the various recording configurations are illustrated: the intact cell or "cell attached" patch, the cell free "inside out" patch, and the "whole cell" configuration. Note that single channel current events are recorded with the cell attached and inside out modes, whereas the whole cell configuration is used to record macroscopic currents. close to the threshold for the activation of voltage dependent $\mathrm{Ca}^{2+}$ channels, and it is activity from these channels that leads to the appearance of spontaneous, regenerating action potentials in the unstimulated PHHI $\beta$ cell. ${ }^{56}$ Because $\mathrm{Ca}^{2+}$ influx is a key determinant of insulin secretion under normal conditions (fig 2), inappropriate $\mathrm{Ca}^{2+}$ channel activity will readily account for the unregulated secretion of insulin in PHHI (fig 1B).

Recordings of action potential currents from PHHI $\beta$ cells indicate that they are regulated, as in normal $\beta$ cells, by changes in the cell membrane potential. Thus, under voltage clamp conditions, hyperpolarisation of the membrane will terminate action potential firing and lead to the inhibition of voltage gated $\mathrm{Ca}^{2+}$ channels. The consequences of this are important. First, the findings suggest that agents that hyperpolarise the $\beta$ cell by non- $\mathrm{K}_{\text {ATP }}$ channel dependent events-for example, $\alpha_{2}$-agonists, ${ }^{61}$ might be clinically beneficial in alleviating hypoglycaemia (fig 7). Second, because a link between loss of $\mathrm{K}_{\mathrm{ATP}}$ channels and insulin hypersecretion has been established, the implications are that blockers of voltage gated $\mathrm{Ca}^{2+}$ channels might be of value in the clinical management of PHHI. ${ }^{60}$

\section{Uncontrolled $\mathrm{Ca}^{2+}$ signals and treatment for $\mathbf{H I}$}

Nifedipine was first used in PHHI treatment after in vitro studies documented the appearance of spontaneous electrical activity in PHHI $\beta$ cells and their inhibition by verapamil. Postoperatively, the patient continued to experience hypoglycaemic episodes and the nifedipine option was then introduced to prevent a second surgical resection of the pancreas. This resulted in both a stabilisation of blood glucose concentrations and an increased tolerance to fasting in the patient. ${ }^{60}$ Since then there have been other successful reports of nifedipine treatment, ${ }^{62}$ but nifedipine regimens can also be ineffective in the control of hypoglycaemia. ${ }^{63}$ The lack of responsiveness of patients with $\mathrm{HI}$ to blockers of voltage gated $\mathrm{Ca}^{2+}$ channels is surprising, but recent findings might provide a clue to understanding this.

We investigated the mechanism of $\mathrm{Ca}^{2+}$ dependent insulin secretion using $\beta$ cells isolated from 11 patients with PHHI after pancreatectomy. In these tissues we found great variability in the function of voltage gated $\mathrm{Ca}^{2+}$ channels. Of particular importance was the fact that it was not possible to record functionally operational channels in six of 11 patients, although they were recorded in $100 \%$ of normal human $\beta$ cell controls. ${ }^{63}$ What is not yet clear is the mechanisms that determine an apparent causal relation between loss of $\mathrm{K}_{\mathrm{ATP}}$ channels and defects in voltage gated $\mathrm{Ca}^{2+}$ channels. It is possible that the membrane environment of the PHHI $\beta$ cell, which is permanently depolarised, leads to the downregulation of voltage gated $\mathrm{Ca}^{2+}$ channels, either at a functional level or by preventing gene transcription. Equally, it is also possible that SUR1 dependent interactions with voltage gated $\mathrm{Ca}^{2+}$ channels are involved. A key question that 


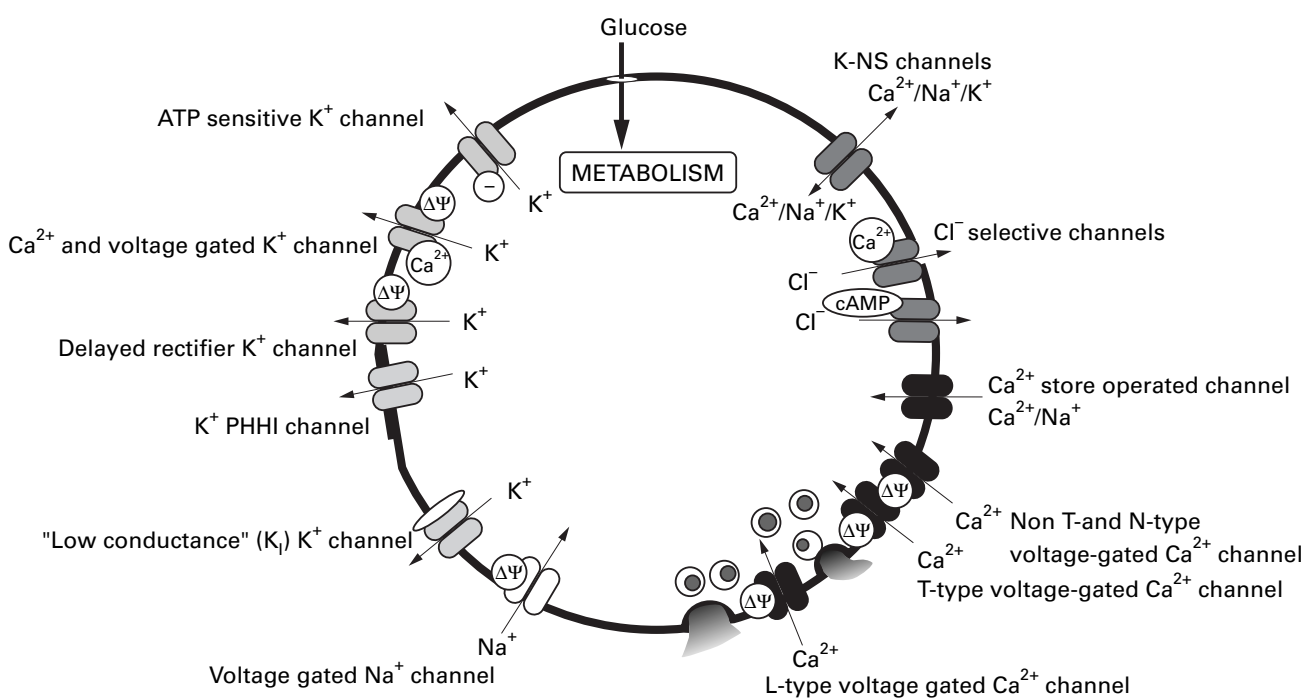

Figure 7 Ion channels in insulin secreting cells. $\beta$ Cells possess a number of ion channel families that are important in the control of the regulated release of insulin. In addition to the $K_{A T P}$ channel, other important $K^{+}$channels include: the large conductance $\mathrm{Ca}^{2+}$ and voltage gated or $K_{C a}$ channel, the delayed rectifier $K^{+}$channel, a low conductance receptor mediated $K^{+}$channel $\left(K_{\nu}\right)$, and a $K^{+}$channel identified in persistent hyperinsulinaemic hypoglycaemia of infancy (PHHI) $\beta$ cells as having sulphonylurea sensitivity and to be regulated by diazoxide, the $K_{\text {PHHI }}$ channel. ${ }^{55}$ The $\beta$ cell possesses tetrodotoxin sensitive voltage gated $\mathrm{Na}^{+}$channels, which contribute to the depolarisation phase of the action potential. The major Ca ${ }^{2+}$ channels in $\beta$ cells are voltage activated and therefore responsible for $\mathrm{Ca}^{2+}$ entry after depolarisation of the membrane. In human $\beta$ cells, two types have been described - the L-type (long lasting) and T-type (transient) —and there is also evidence for "non-T-type" and "N-type" channels. At least two types of $\mathrm{Cl}^{-}$selective anion channels are present: one of which is Ca ${ }^{2+}$ regulated whereas the other is cAMP regulated. Finally, two types of non-selective cation channels have been described, which are permeable to $\mathrm{Na}^{+}, \mathrm{K}^{+}$, and $\mathrm{Ca}^{2+}$, and might be involved with the refilling of intracellular stores after agonist induced stimulation: non-selective cation $\left(I_{C R A N}\right)$ channels.

arises from this work is: how can insulin release be controlled if voltage gated $\mathrm{Ca}^{2+}$ channels fail to operate in PHHI $\beta$ cells? One explanation for this is that other $\mathrm{Ca}^{2+}$ selective ion channels are active in PHHI $\beta$ cells as a consequence of the primary defect in $\mathrm{K}_{\mathrm{ATP}}$ channels. Evidence to support this possibility comes from in vitro studies using the agent maitotoxin - a dinoflagellate toxin and activator of $\mathrm{I}_{\mathrm{CRAN}}$ channels in $\beta$ cells (figs 2 and 7). In PHHI $\beta$ cells that lack voltage dependent mechanisms to increase the cytosolic $\mathrm{Ca}^{2+}$ concentration, we have shown that maitotoxin readily raises cytosolic $\mathrm{Ca}^{2+}$ concentrations, thus implicating $\mathrm{I}_{\mathrm{CRAN}}$ channels in the pathogenesis of PHHI. ${ }^{63}$ Together, these findings could account for both the clinical variability of patients' responses to nifedipine, and unregulated insulin release in PHHI.

\section{Other $\mathrm{K}^{+}$channels and PHHI $\beta$ cells}

In $\beta$ cells, several types of $\mathrm{K}^{+}$channels are known to contribute to the complex electrophysiological profile that is generated in the presence of stimulatory concentrations of glucose (fig 7). This essentially consists of cycles or waves of electrical activity with superimposed action potentials. Whereas closure of $\mathrm{K}_{\mathrm{ATP}}$ channels crucially determines the initial depolarisation of the cell membrane, other $\mathrm{K}^{+}$ channels are subsequently involved in the generation of action potentials and establishing the oscillations of electrical activity. ${ }^{4}$ The delayed rectifier $\left(\mathrm{K}_{\mathrm{v}}\right)$ and $\mathrm{Ca}^{2+}$ and voltage gated $\left(\mathrm{K}_{\mathrm{Ca}}\right)$ $\mathrm{K}^{+}$channels are the major voltage dependent $\mathrm{K}^{+}$channels in $\beta$ cells, and contribute to the repolarisation phase of the action potential. ${ }^{64-68}$ In recent experiments, we made several conclusions about the properties of $\mathrm{K}_{\mathrm{V}}$ and $\mathrm{K}_{\mathrm{Ca}}$ channels in $\beta$ cells isolated from seven patients with
PHHI. ${ }^{69}$ First, we found that the channels were functionally operational and that they were voltage dependent. Second, the voltage dependency of activation varied little between control (human) and disease tissue. Finally, we found that the numbers of channels in each cell were not significantly different between control and PHHI, and neither were there any major differences in their pharmacological properties. Only one minor aspect of the biophysical properties of $\mathrm{K}_{\mathrm{Ca}}$ and $\mathrm{K}_{\mathrm{v}}$ channels was found to be different in PHHI $\beta$ cells: an increase in the magnitude of currents at membrane potential values outside of the normal physiological range. This could have arisen from a shift in the voltage dependent activation profile of these channels, an effect that would make these channels relatively more sensitive to depolarisation of the membrane. Such findings are clinically relevant to PHHI treatment, because they suggest that selective activators of $\mathrm{K}_{\mathrm{Ca}}$ and/or $\mathrm{K}_{\mathrm{v}}$ channels, were they available, might be potentially useful as alternatives to diazoxide and somatostatin at inhibiting insulin release in vivo.

\section{Animal models of PHHI}

Transgenic animal models of PHHI have also been developed in which the consequences of $\mathrm{K}_{\text {ATP }}$ channel dysfunction were studied in vivo. In one example of this work, transgenic mice were engineered to express a "dominant negative" version of Kir6.2 in $\beta$ cells. ${ }^{70}$ Substitution of a glycine residue for serine at position 132 within the $\mathrm{K}^{+}$ion conducting region of Kir6.2 terminates $\mathrm{K}_{\mathrm{ATP}}$ channel activity, thereby mimicking this pathophysiological aspect of PHHI $\beta$ cells. Affected mice were found to develop hyperinsulinaemic hypoglycaemia during the 
neonatal period, and $\beta$ cells isolated from the animals had remarkably similar properties to human PHHI $\beta$ cells: no $\mathrm{K}_{\mathrm{ATP}}$ channel function, depolarised resting membrane potentials, and raised concentrations of cytosolic $\mathrm{Ca}^{2+}$. As the animals develop, hypoinsulinaemia and hyperglycaemia (that is, the onset of diabetes) follow the period of hyperinsulinaemic hypoglycaemia. These animals were found to have a higher frequency of apoptotic $\beta$ cells in the prediabetic period compared with control animals, and for the first time this implicated programmed cell death as the reason for loss of $\beta$ cells in PHHI. ${ }^{70}$ The concept of $\beta$ cell "burn out" has a direct clinical correlation. In a recent review Glaser and colleagues $^{53}$ discuss how long term, intensive treatment of patients with PHHI with somatostatin leads to remission of symptoms without the need for surgery. In such cases, it seems likely that this is caused by the long term destruction of $\beta$ cells, which might result from unregulated $\mathrm{Ca}^{2+}$ entry, or indeed be a direct consequence of somatostatin treatment, which is known to be apoptogenic. ${ }^{71}$

KIR6.2 knockout (KIR6.2 $2^{-/}$) animals have also been created. ${ }^{72}$ In these animals, Kir6.2 function was specifically and selectively eliminated from pancreatic $\beta$ cells. The developmental profile of these animals might have been expected to parallel that of the "dominant negative" mice; however, this was not the case. Quite surprisingly, $\beta$ cells from KIR6.2 ${ }^{-/-}$ animals were less reminiscent of the human PHHI $\beta$ cell than insulin secreting cells isolated from "dominant negative" mice..$^{73}$ One other interesting feature of the KIR6.2 $2^{-/-}$mice is that despite having impaired glucose dependent insulin release, both in vitro and in vivo, they have normal postprandial blood glucose values. ${ }^{72}$ This might implicate a negative correlation between Kir6.2 operation and insulin receptor expression in skeletal muscle tissue, which will tend to improve peripheral glucose clearance despite impaired insulin secretion. A SUR1 knockout (SUR1 $\left.{ }^{-1}\right)$ )" mouse has also been developed recently. ${ }^{74}$ In these animals, the $\beta$ cell resting membrane potential is depolarised with respect to normal values, and spontaneous $\mathrm{Ca}^{2+}$ action potentials are inhibitable by nifedipine. These properties are once again reminiscent of the human PHHI $\beta$ cell; however, the physiological regulation of glucose homeostasis differs from the human disease, in that SUR1 $1^{-/}$animals apparently fail to increase insulin output in response to an increased glucose load. ${ }^{74}$

\section{$H I$ and acquired defects in $K_{\text {ATP }}$ channel operation}

Some children with congenital hyperinsulinism present with milder symptoms of hyperinsulinaemic induced hypoglycaemia than is described for PHHI, often with episodes of hypoglycaemia that are sporadic, occur postprandially, and are sensitive to diazoxide. ${ }^{75}{ }^{76} \mathrm{In}$ addition, some patients also present symptoms much later in life, even in adulthood.$^{77}$ In these cases, hyperinsulinism can be inherited in an autosomally dominant fashion and is not prin- cipally linked to defects in the SUR1 or KIR6.2 genes. So far, mutations in two other genes, both associated with glucose homeostasis and acquired $\mathrm{K}_{\text {ATP }}$ channel dysfunction in $\beta$ cells, have now been shown to give rise to clinically distinct forms of HI: HI-GK and HI-GLUD1 (fig 1C).

HI-GK arises from defects in the glucokinase gene $(\mathrm{GK}) .^{75}$ Gene mutations that decrease the sensitivity of the enzyme for glucose are known to give rise to maturity onset diabetes of the young type $2 .^{78}$ In contrast, the mutations described in patients with HI-GK result in the generation of an "activated" gene product with a greatly increased sensitivity to glucose. It has been suggested that these mutations result in excessive ATP production in $\beta$ cells and the inappropriate closure of $\mathrm{K}_{\mathrm{ATP}}$ channels (fig 1C).

The GLUD1 gene encodes the enzyme glutamate dehydrogenase $(\mathrm{GDH})$, which links glutamate metabolism with the citric acid cycle and catalyses the conversion of glutamate to $\alpha$-ketoglutarate. The term HI-GLUD1 has been introduced to describe patients who present with a clinical phenotype of hyperinsulinism associated with hyperammoneamia. ${ }^{76}$ Under normal conditions, the activity of GDH is controlled by allosteric inhibition by GTP. In some patients with HI-GLUD1, defects in the region of GLUD1 encoding the GTP binding domain of the enzyme have been identified that lead to a decrease in the sensitivity of GDH to GTP. This results in an "activated enzyme" complex, which in the liver results in excessive ammonia production, whereas in $\beta$ cells, after dietary intake, leucine induced stimulation of glutamate dehydrogenase is presumed to increase the flux of glutamine into the citric acid cycle. As in the case of $\mathrm{HI}-\mathrm{GK}$, the predicted $\beta$ cell response is a net increase in the cytosolic ATP concentration, leading to enforced closure of $\mathrm{K}_{\mathrm{ATP}}$ channels, a constant depolarisation of the membrane, uncontrolled voltage gated $\mathrm{Ca}^{2+}$ channel activity, and hyperinsulinism as a consequence (fig 1C). Recently, a different mode of GDH activation was described in a patient with severe hyperinsulism hyperammonemia syndrome. ${ }^{79}$ In this case, the patient was heterozygous for two mutations outside of the GTP binding domain of the enzyme (A1401C, N410T), which were associated with a constitutively high level of GDH activity.

Therefore, the loss of $\mathrm{K}_{\text {ATP }}$ channel operation is a common pathophysiological event in the onset of HI-GK, HI-GLUD, and PHHI. However, it should also be noted that because $\mathrm{K}_{\text {ATP }}$ channels are "operational" in patients with HI-GK and HI-GLUD, these patients show good clinical responses to diazoxide, whereas patients with PHHI do not.

NES2Y: a PHHI derived human $\beta$ cell line While studying the physiology of PHHI $\beta$ cells we discovered recently that these cells have the potential to proliferate spontaneously in vitro. We have studied one $\beta$ cell line-designated NES2Y - in detail. ${ }^{80}$ NES2Y cells reproduce the properties and key features of acutely isolated PHHI $\beta$ cells, namely: (1) they lack 
operational $\mathrm{K}_{\mathrm{ATP}}$ channels; (2) they have greatly impaired cytosolic $\mathrm{Ca}^{2+}$ signalling mechanisms; (3) they constitutively release insulin at an increased rate in the absence of stimuli; and (4) they show a limited responsiveness to glucose through the $K_{\text {ATP }}$ channel independent or glucose augmentation pathway. ${ }^{9}$ Because PHHI is a rare condition, the availability of these cells is an important asset to ongoing studies of the molecular pathophysiology of the condition.

\section{In vitro gene therapy for PHHI}

In addition to loss of $\mathrm{K}_{\mathrm{ATP}}$ channel operation, NES2Y $\beta$ cells also have impaired expression of the homeodomain transcription factor PDX $1 .{ }^{18}$ In recent studies, we found that defects in the functional operation of NES2Y $\beta$ cells can be overcome by triple transfection of the cells with cDNA molecules encoding SUR1, Kir6.2, and PDX1. This has led to the generation of a fully glucose responsive human $\beta$ cell line-designated NISK9 cells. ${ }^{80}$ The properties of $\mathrm{K}_{\mathrm{ATP}}$ channels expressed in the NISK9 $\beta$ cells are identical to those in native tissue (inwardly rectifying, inhibited by cytosolic ATP in a concentration dependent manner, activated by ADP in the presence of ATP, modulated by diazoxide and tolbutamide, and so on), and their operation has clear functional consequences. Not only did the transfection event underpin the development of glucose responsiveness within a physiologically relevant concentration range, but it also led to a considerable decrease in the rate of insulin release under basal conditions. This has provided further proof of the causal relation between $\mathrm{K}_{\mathrm{ATP}}$ channel defects and insulin hypersecretion in PHHI.

It is currently unclear why NES2Y cells (and other PHHI derived $\beta$ cells) proliferate in culture. Because these cells have defects in PDX1 expression, ${ }^{18}$ and because PDX1 is involved in pancreatic $\beta$ cell lineage determination, ${ }^{17}$ NES2Y cells may represent a stage in islet cell development at which the cells have retained the ability to replicate while attaining a $\beta$ cell like phenotype. The wider implications of this possibility and the role of PDX1 in HI clearly need to be investigated. Alternatively, it is also possible that unregulated $\mathrm{Ca}^{2+}$ influx in PHHI derived tissue is having a permissive role on $\mathrm{Ca}^{2+}$ dependent genes associated with cell cycle events.

\section{Concluding remarks}

Since the genes associated with HI were first identified in 1994-5, we have moved in a relatively short period of time to a position of understanding the defective gene products, and how these impact upon the physiology of insulin release. A meaningful interface of applied physiology and clinical medicine has been established, and it is already clear that information gained from pathophysiological studies is now being used in the clinical environment, both in terms of prognosis and management of the condition (A AynsleyGreen et al, 1999, unpublished) ${ }^{81}$ Armed with a greater awareness of the pathophysiology of
PHHI $\beta$ cells, and the availability of an in vitro model system, it might also be possible in the future to isolate $\beta$ cells from patients with PHHI after pancreatectomy, and genetically engineer the cells for subsequent autotransplantation. Clearly, this is a long term objective, but one that can now be advanced through the availability of PHHI derived $\beta$ cell lines.

Work in our laboratory is supported by the British Diabetic Association and the Medical Research Council. This collaborative group initiative was supported by a European Union funded concerted action grant (BMH4-CT98-3284) from the European Network for Research into Hyperinsulinism in Infancy (ENRHI).

1 Kulkarni RN, Bruning JC, Winnay JN, Postic C, Magnuson MA, Kahn CR. Tissue-specific knockout of the insulin receptor in pancreatic $\beta$-cells creates an insulin secretory defect similar to that in type 2 diabetes. Cell 1999;96:329

2 Leibiger B, Moede T, Schwarz T, et al. Short-term regulation of insulin gene transcription by glucose. Proc regulation of insulin gene transcription
Natl Acad Sci U S A 1998;95:9307-12.

3 Aspinwall CA, Lakey JR, Kennedy RT. Insulin-stimulated insulin secretion in single pancreatic $\beta$-cells. $\mathcal{F}$ Biol Chem 1999;274:6360-5.

4 Dunne MJ, Petersen OH. Potassium selective ion channels in insulin-secreting cells; physiology, pharmacology and their role in stimulus secretion coupling. Biochim Biophys Acta 1991;1071:67-82.

5 Wollheim CB, Sharp GWG. Regulation of insulin release by calcium. Physiol Rev 1981;61:914-73.

6 Roe MW, Worley JF, 3rd, Qian F, et al. Characterization of a $\mathrm{Ca}^{2+}$ release-activated non-selective cation current regulating membrane potential and $[\mathrm{Ca} 2+]_{\mathrm{i}}$ oscillations in transgenically derived $\beta$-cells. F Biol Chem 1998;273:10402-10.

7 Leech CA, Habener JF. A role for $\mathrm{Ca}^{2+}$-sensitive nonselective cation channels in regulating the membrane

$8 \mathrm{~J}$ Lang. Molecular mechanisms and regulation of insulin exocytosis as a paradigm of endocrine secretion. Eur f Biochem 1999;259:3-17.

9 Aizawa T, Komatsu M, Asanuma N, Sato Y, Sharp GWG. Glucose action "beyond ionic events" in the pancreatic $\beta$-cell. Trends Pharmacol Sci 1998;19:496-9.

10 Komatsu M, Aizawa T, Yokokawa N, Sato Y, Takasu N, Yamada T. Mastoparan-induced hormone release from rat pancreatic islets. Endocrinology 1992;30:221-8.

1 Gembal M, Gilon P, Henquin JC. Evidence that glucose can control insulin release independently from its action on ATP-sensitive $\mathrm{K}^{+}$channels in mouse B cells. $\mathcal{F}$ Clin Invest 1992;89:1288-95.

12 Best L, Yates AP, Tomlinson S. Stimulation of insulin secretion by glucose in the absence of diminished $\left({ }^{86} \mathrm{Rb}^{+}\right)$ permeability. Biochem Pharmacol 1992;43:2483-5.

13 Straub SG, James RFL, Dunne MJ, Sharp GWG. Glucose activates both $K_{A T P}$ channel-dependent and $K_{\text {ATP }}$ channelindependent signalling pathways in human islets. Diabetes 1998;47:758-64.

14 Straub SG, James RFL, Dunne MJ, Sharp GWG. Glucose augmentation of mastoparan-stimulated insulin secretion in rat and human pancreatic islets. Diabetes 1998;47:1053in 7 .

15 Yajima $\mathrm{H}$, Komatsu $\mathrm{M}$, Schermerhorn $\mathrm{T}$, et al. cAMP enhances insulin secretion by an action on the ATPsensitive $\mathrm{K}^{+}$channel-independent pathway of glucose signalling in rat pancreatic islets. Diabetes 1999;48:1006-12.

16 Melloul D, Ben-Neriah Y, Cerasi E. Glucose modulates the binding of an islet-specific factor to a conserved sequence within the rat I and the human insulin promoters. Proc Natl Acad Sci U S A 1993;90:3865-9.

17 Jonsson J, Carlsson L, Edlund T, Edlund H. Insulinpromoter-factor 1 is required for pancreas development in mice. Nature 1994;371:606-9.

18 Macfarlane WM, Cragg H, Docherty HM, et al. Impaired expression of transcription factor IUF1 in a cell line derived from a patient with persistent hyperinsulinaemic hypoglycaemia of infancy (nesidioblastosis). FEBS Lett 1997;413:304-8.

19 Ashcroft FM, Gribble FM. Correlating structure and function in ATP-sensitive $\mathrm{K}^{+}$channels. Trends Neurosci 1998;21:288-94.

20 Aguilar-Bryan L, Clement JP, IV, Gonzalez G, Kunjilwar K, Babenko A, Bryan J. Toward understanding the assembly and structure of $\mathrm{K}_{\mathrm{ATP}}$ channels. Physiol Rev 1998;78:22745 .

21 Aguilar-Bryan L, Nichols CG, Wechsler SW, et al. Cloning of the $\beta$-cell high-affinity sulphonylurea receptor: a regulator of insulin secretion. Science 1995;268:423-6.

22 Inagaki N, Gonoi T, Clement JP, 4th, et al. Reconstitution of $\mathrm{IK}_{\mathrm{ATP}}$ : an inward rectifier subunit plus the sulphonylurea receptor. Science 1995;270:1166-70.

23 Tusnady GE, Bakos E, Varadi A, Sarkadi B. Membrane topology distinguishes a subfamily of the ATP-binding topology distinguishes a subfamily of the ATP-binding

24 Inagaki N, Gonoi T, Clement JP, et al. A family of sulphonylurea receptors determines the pharmacological propertie of ATP-sensitive $\mathrm{K}^{+}$channels. Neuron 1995;16:1011-17. 
25 Sakura H, Ämmälä C, Smith PA, Gribble FM, Ashcroft FM. Cloning and functional expression of the cDNA encoding a novel ATP-sensitive potassium channel expressed in pancreatic $\beta$-cells, brain, heart and skeleta

26 Clement JP, 4th, Kunjilwar K, Gonzalez G, et al. Association and stoichiometry of $\mathrm{K}_{\mathrm{ATP}}$ channel subunits. Neuron 1997;18:827-38

27 Shyng SL, Nichols CG. Octameric stoichiometry of the $\mathrm{K}_{\mathrm{ATP}}$ channel complex. F Gen Physiol 1997;110:655-64.

28 Aguilar-Bryan L, Bryan J. Molecular biology of ATPsensitive $\mathrm{K}^{+}$channels. Endocr Rev 1999;20:101-35.

29 Sharma N, Crane A, Clement IV JP, et al. The C-terminus of SUR1 is required for trafficking of $\mathrm{K}_{\mathrm{ATP}}$ channels. $\mathcal{F} \mathrm{Biol}$ Chem 1999;274:20628-32.

30 Zerangue N, Schwappach B, Jan YN, Jan LY. A new ER trafficking signal regulates the subunit stoichiometry of plasma ficking signal regulates the subunit stoichiometry of

31 Begiun P, Nagashima K, Nishimura M, Ganoi T, Seino S PKA-mediated phosphorylation of the human $\mathrm{K}_{\mathrm{ATP}}$ channel: separate role of Kir6.2 and SUR
ylation. $E M B O \mathcal{1}$ 1999;18:4722-32.

32 Ashfield R, Gribble FM, Ashcroft SJH, Ashcroft FM. Identification of the high-affinity tolbutamide site on the SUR1 subunit of the $\mathrm{K}_{\mathrm{ATP}}$ channel. Diabetes 1999;48:1341-7.

33 Uhde I, Toman A, Gross I, Schwanstecher C, Schwanstecher $M$. Identification of the potassium channel opener site on sulfonylurea receptors. 7 Biol Chem 1999;274:28079-82.

34 Dorschner H, Brekardin E, Uhde I, Schwanstecher C, Schwanstecher M. Stoichiometry of sulfonylurea-induced ATP-sensitive potassium channel closure. Mol Pharmacol 1999;55:1060-6.

35 Ashcroft FM, Ashcroft SJH. The sulphonylurea receptor. Biochim Biophys Acta 1992;1175:45-59.

36 Chutkow WA, Simon MC, Le Beau MM, Burant CF. Cloning, tissue expression and chromosomal localisation of SUR2, the putative drug-binding subunit of cardiac, skeletal muscle and vascular $\mathrm{K}_{\mathrm{ATP}}$ channels. Diabetes 1999:45:1439-45.

37 Proks P, Ashcroft FM. Phentolamine block of $\mathrm{K}_{\mathrm{ATP}}$ channels is mediated by Kir 6.2. Proc Natl Acad Science USA 1998;94:11716-20

38 Lawson K. Potassium channel activation: a potential therapeutic approach? Pharmacol Ther 1996;70:39-63.

39 Lebrun P, Antoine M-H, Ouedraogo R, et al. Activation of ATP-dependent $\mathrm{K}^{+}$channels and inhibition of insulin release; effect of BPDZ-62. I Pharmacol Exp Ther 1996;277;156-62.

40 Dunne MJ. Effects of pinacidil, RP 49356 and nicorandil on ATP-sensitive potassium channels in insulin-secreting ATP-sensitive potassium channels in
cells. Br f Pharmacol 1990;99:487-92.

41 Nestorowicz A, Glaser B, Wilson BA, et al. Genetic heterogeneity in familial hyperinsulinism. Hum Mol Genet 1998;7:1119-28.

42 Otonkoski T, Ämmälä C, Huopio $\mathrm{H}$, et al. A point mutation inactivating the sulfonylurea receptor causes the severe form of persistent hyperinsulinemic hypoglycaemia of infancy in Finland. Diabetes 1999;48:408-15.

43 Thomas PM, Wohllk N, Huang E, et al. Inactivation of the first nucleotide-binding fold of the sulfonylurea receptor, and familial persistent hyperinsulinemic hypoglycemia of infancy. Am $\mathcal{F}$ Hum Genet 1996;59:510-18.

44 Kentrup H, Altmüller J, Karhausen S, Hauffa B, Pfäffle R. Novel mutation of the sulfonylurea receptor-1 (SUR1) gene in persistent hyperinsulinemic hypoglycaemia of gene in persistent hyperinsulinemic
infancy (PHHI). Horm Res 1999;55:45.

45 Nestorowicz A, Wilson BA, Schoor KP, et al. Mutations in the sulfonylurea receptor gene are associated with familial hyperinsulinism

46 Verkarre V, Fournet JC, de Lonlay P, et al. Paternal mutation of the sulfonylurea receptor (SUR1) gene and maternal loss of $11 \mathrm{p} 15$ imprinted genes lead to persistent hyperinsulinism in focal adenomatous hyperplasia. $\mathcal{F}$ Clin Invest 1998;102:1286-91

47 De Lonlay-Debeney P, Poggi-Travert F, Fournet JC, et al. Clinical features of 52 neonates with hyperinsulinism. $N$ Engl f Med 1999;340:1169-75.

48 Dunne MJ, Kane C, Shepherd RM, et al. Familial persistent hyperinsulinaemic hypoglycaemia of infancy and mutations in the sulphonylurea receptor. $N$ Engl $f \mathrm{Med}$ 1997;336:703-6.

49 Meissner T, Brune W, Mayatepek E. Persistent hyperinsulinaemic hypoglycemia of infancy: therapy, clinical outcome
and mutational analysis. Eur $\mathcal{7}$ Pediatr 1997;156:754-7.

50 Nestorowicz A, Inagaki N, Gonoi T, et al. A nonsense mutation in the inward rectifier potassium channel gene, Kir6.2, is associated with familial hyperinsulinism. Diabetes 1997;46:1743-8.

51 Hupio H, Komulainen J, Rissanen J, Lenko H-L, Laakso M, Otonkoski T. A novel point mutation in sulfonylurea receptor 1 gene associates to diazoxide-responsive form of congenital hyperinsulinism. Horm Res 1997;55:15P.

52 Thomas PM, Cote GJ, Wohllk N, et al. Mutations of the sulphonylurea receptor gene in familial persistent hyperinsulinemic hypoglycaemia of infancy Science 1995;268:426-9.

53 Glaser B, Landau H, Permutt MA. Neonatal hyperinsulinism. Trends Endocrinol Metab 1999;10:55-61.

54 Aynsley-Green A, Polak JM, Bloom SR, et al. Nesidioblastosis of the pancreas: definition of the syndrome and the management of the severe neonatal hyperinsulinaemic
hypoglycaemia. Arch Dis Child 1981;56:496-508.
55 Kane C, Lindley KJ, Johnson PRV, et al. Therapy for persistent hyperinsulinaemic hypoglycaemia of infancy (PHHI); understanding the responsiveness of $\beta$-cells to diazoxide and somatostatin. F Clin Invest 1997;100:1888 93.

56 Kane C, Shepherd RM, Squires PE, et al. Loss of functional $\mathrm{K}_{\mathrm{ATP}}$ channels in pancreatic $\beta$-cells causes persistent hyperinsulinaemic hypoglycaemia of infancy. Nat Med 1996;2:1344-7.

57 Dunne MJ, Cosgrove KE, Shepherd RM, Ämmälä C. Potassium channels, sulphonylurea receptors and control 53 .

58 Shyng SL, Ferrigni T, Shepard JB, et al. Functional analyses of novel mutations in the sulphonylurea receptor 1 associa ted with persistent hyperinsulinaemic hypoglycaemia of infancy. Diabetes 1998;47:1145-51.

59 Ryan F, Devaney D, Joyce C, et al. Hyperinsulinism: molecular aetiology of focal disease. Arch Dis Child 1998;79:445-7

60 Lindley KJ, Dunne MJ, Kane C, et al. Ionic control of $\beta$-cell function in nesidioblastosis. A possible therapeutic role for calcium channel blockade? Arch Dis Child 1996;74:373-8.

61 Ämmälä C, Larsson O, Berggren P-O, et al. Inositol trisphosphate-dependent periodic activation of a $\mathrm{Ca}^{2+}$ activated $\mathrm{K}^{+}$conductance in glucose-stimulated pancreatic $\beta$-cells. Nature 1991;353:849-52.

62 Eichmann D, Hufnagel M, Quick P, Santer R. Treatment of hyperinsulinaemic hypoglycaemia with nifedipine. Eur $\mathcal{F}$ 999;158:204-6

63 Cosgrove KE, Shepherd RM, Hashmi MN, et al. The role of calcium ions in determining insulin hypersecretion in patients with persistent hyperinsulinaemic hypoglycaemia of infancy (PHHI) Horm Res 1999:55:15P.

64 Bokvist K, Rorsman P, Smith PA. Effect of external tetraethylammonium ions and quinine on delayed rectifying $\mathrm{K}^{+}$channels in mouse pancreatic $\beta$-cells. F Physiol 1990;423:311-25.

65 Rorsman P, Trube G. Calcium and delayed potassium currents in mouse $\beta$-cells under voltage-clamp conditions. 7 Physiol 1986;371:531-50.

66 Smith PA, Bokvist K, Arkhammar P, Berggren P-O, Rorsman P. Delayed rectifier and calcium-activated $\mathrm{K}^{+}$ channels and their significance for action potential repolarization in mouse pancreatic $\beta$-cells. $\mathcal{f}$ Gen Physiol 1990;95:1041-59.

67 Kalman K, Nguyen A, Tseng-Crank J, et al. Genomic organisation, chromosomal localization, tissue distribution, and biophysical characterization of a novel mammalian Shaker-related voltage-gated potassium channel, Kv1.7. F Biol Chem 1998;273:5851-7.

68 Roe MW, Worley JF, Mittal AA, et al. Expression and function of pancreatic $\beta$-cell delayed rectifier $\mathrm{K}^{+}$channels. Role in stimulus-secretio

69 Cosgrove KE, Ämmälä C, James RFL, Dunne MJ. Properties of voltage-dependent $\mathrm{K}^{+}$currents in human pancreatic $\beta$-cells following loss of $\mathrm{K}_{\mathrm{ATP}}$ channel function. $\mathcal{F}$ Physiol 1998;509:189P.

70 Miki T, Tashiro F, Iwanaga $\mathrm{T}$, et al. Abnormalities of pancreatic islets by targeted expression of a dominantnegative $\mathrm{K}_{\text {tp }}$ channel. Proc Natl Acad Science $U S A$ 1997;94:11969-73.

71 Patel YC, Srikant CB. Somatostatin receptors. Trends Endocrinol Metab 1997;8:398-405.

72 Miki $\mathrm{T}$, Nagashima K, Tashiro $\mathrm{F}$, et al. Defective insulin secretion and enhanced insulin action in $\mathrm{K}$ tp deficient mice. Proc Natl Acad Sci U S A 1998;95:10402-6.

73 Miki T, Nagashima K, Seino S The structure and function of the ATP-sensitive $\mathrm{K}^{+}$channel in insulin-secreting
pancreatic $\beta$-cells. $\mathcal{F}$ Mol Endocrinol 1999:22 113-23.

74 Seghers VJ, Nakazaki M, Gonzalez $\mathrm{G}$, et al. Analysis of $\mathrm{K}_{\mathrm{ATP}}$ channel deficient SUR1-mice. Diabetes 1999;48(suppl 1):A34

75 Glaser B, Kesavan P, Heyman M, et al. Familial hyperinsulinism caused by an activating glucokinase mutation. $N$ Engl F Med 1998;338:226-30.

76 Stanley CA, Lieu YK, Hsu BY, et al. Hyperinsulinism and hyperammonemia in infants with regulatory mutations of the glutamate dehydrogenase gene. $N$ Engl $f$ Med 1998;338:1352-7.

77 Service FJ, Natt N, Thompson GB, et al. Non-insulinoma pancreatogenous hypoglycaemia: a novel syndrome of hyperinsulinemic hypoglycaemia in adults independent of mutations in Kir6.2 and SUR1 genes. 7 Clin Endocrinol Metab 1999;84:1582-9.

78 Froguel P, Velho G. Molecular genetics of maturity-onset diabetes of the young. Trends Endocrinol Metab

79 Yorifuji T, Muroi J, Uematsu A, Hiramatsu H, Momoi T. Hyperinsulinism-hyperammonemia syndrome caused by mutant glutamate dehydrogenase accompanied by novel enzyme kinetics. Hum Genet 1999;104:476-9

80 MacFarlane WM, Chapman JC, Shepherd RM, et al. Engineering a glucose-responsive human insulin-secreting cell line from islets of Langerhans isolated from a patient with persistent hyperinsulinaemic hypoglycaemia of infancy (PHHI). f Biol Chem 1999;274:34059-66.

81 Aynsley-Green A, Dunne MJ, James, Lindley KJ. Ions and genes in persistent hyperinsulinaemic hypoglycaemia of infancy; a commentary on the implications for tailoring treatment to disease pathogenesis. $\mathcal{F}$ Pediatr Endocrinol 1998;11:121-9. 